Research article

\title{
TWO MORPHOLOGICALLY DISTINCT FORMS OF DEMODEX MITES FOUND IN DOGS WITH CANINE DEMODICOSIS FROM VLADIVOSTOK, RUSSIA
}

\author{
MOSKVINA Tatyana Vladimirovna* \\ Far Eastern Federal University, School of Natural Sciences, Russian Federation, Vladivostok, \\ 8 Suhanova str.
}

(Received 07 August 2016, Accepted 20 January 2017)

\begin{abstract}
The aim of this study was to investigate the morphology of Demodex canis and Demodex sp. cornei found in six dogs with canine demodicosis. A deep skin scraping technique was used for Demodex mite detection. Measurement data of 52 adult $D$. canis mites (26 females, 25 males and one specimen whose sex could not be determined) and 39 adult Demodex sp. cornei mites (22 females, 14 males and three specimens whose sex could not be determined) were reported. The correlation between body size of both Demodex species were estimated by the Student's t-test. There was a significant correlation between short-tail and long-tail forms and total body length and length of the podosoma and opisthosoma $(\mathrm{p}<0.05)$. A significant difference was not found between the length of the gnathosoma and short-tail and long-tail forms ( $p>0.05)$. Demodex sp. cornei and D. canis, found in dogs from Vladivostok, were smaller than species from other countries. However, the present data did not significantly differ from other studies with D. canis and Demodex sp. cornei descriptions.
\end{abstract}

Key words: demodicosis; dog; Demodex canis; Demodex cornei

\section{INTRODUCTION}

Canine demodicosis is one of the most well known skin diseases in veterinary practice [1]. Symptoms of demodicosis include alopecia, hyperaemia, erythema, seborrhea, follicular hyperkeratosis, crusts, pustules and dermatitis. The exact causes of mite proliferation are actually unknown. Some authors suspect that, since demodicosis frequently appears in dogs with an immunodeficient status, it is caused by immunosuppressive therapy (such hormones and cytotoxic therapy) or common immunosuppressive diseases such as diabetes mellitus and cancer. Stress can also cause demodicosis, especially in puppies [2,3]. Superficial and deep skin scrapings are used to detect Demodex mites.

\footnotetext{
*Corresponding author: e-mail: rabchan1992@gmail.com
} 
Mites of the genus Demodex (Owen, 1843), included in the family Demodecidae [4], have a small, thin, usually elongated body, with four pairs of rudimentary legs. Their bodies are divided into three distinct tagma: gnathosoma, podosoma and opisthosoma. The gnathosoma has a trapezoidal or rectangular form, and it consists of three-segmented palps, styliform chelicerae, 4-5 rounded bristles and a large hip element. The podosoma consists of four pairs of legs. The opisthosoma usually has an elongated form and has striations.

There are three distinguished Demodex mites in dogs: D. canis, D. injai [5] and Demodex sp. cornei.

Demodex canis (Leydig, 1859) mites were first discovered in 1844 by Simon [6] and were described and named in 1859 by Leydig [7]. All stages of the D. canis life cycle were described in detail by Sokolovskii [8] and French [9]. Demodex canis are wormlike mites, with an elongated body. Their trapezoidal gnathosoma is slightly wider than it is long. The pharyngeal bulb is horseshoe in shape. The epimeral plates are trapezoidal. The opisthosoma is long and its posterior end is pointed. The opisthosomal organ is a chitin tube present in females. Female mites are usually longer than males. Also the size of male mites can be very variable. The adult female has a total body length of 177-265 $\mu \mathrm{m}$, and the male has a total body length of 146-251 $\mu \mathrm{m}$ [1].

Demodex injai (Desch and Hillier, 2003) was first reported in 1997 [5,10]. These mites have a long, thin body, with a total body length of more than twice the length of $D$. canis mites. The opisthosomal organ is present in both sexes.

Demodex sp. Cornei, firstly discovered by Mason, was in detail described in the $20^{\text {th }}$ century [11-15]. Demodex sp. cornei mites have a short and wide body, the opisthosoma end is round and their total body length is 93-165 $\mu \mathrm{m}$. Certain size and qualitative characteristics of Demodex sp. cornei (Table 1), including opisthosoma and podosoma length, total body length, ratio of opisthosoma length to total body length, shape of the opisthosoma end, shape of the epimeral plates and presence of the band-like plate in the lower edge of the fourth coxisternal plate, distinguish it from D. canis [1].

Table 1. Characteristics of two forms of Demodex mites found in dogs $[1,20]$

\begin{tabular}{lcc}
\hline Characteristics & $\begin{array}{c}\text { Short-tail form } \\
\text { (Demodex } \boldsymbol{s p} \text {. cornei) }\end{array}$ & $\begin{array}{c}\text { Long-tail form } \\
\text { (Demodex canis) }\end{array}$ \\
\hline Total body length $(\mu \mathrm{m})$ & $93-165$ & $146-265$ \\
\hline $\begin{array}{l}\text { Length of podosoma }(\mu \mathrm{m}) \\
\text { Length of opisthosoma }(\mu \mathrm{m})\end{array}$ & $39-66$ & $50-81$ \\
$\begin{array}{l}\text { Ratio of opisthosoma length } \\
\text { to total body length }(\%)\end{array}$ & $36-99$ & $74-167$ \\
$\begin{array}{l}\text { Shape of body end } \\
\text { Shape of epimeral plates }\end{array}$ & $38-50$ & pointed \\
$\begin{array}{l}\text { Band-like plate in the lower edge } \\
\text { of fourth coxisternal plate }\end{array}$ & rectangular & trapezoidal \\
\begin{tabular}{l} 
Microhabitat \\
\hline
\end{tabular} & present & absent \\
\hline
\end{tabular}


However, some molecular data show that D. cornei is probably just a morphological variant of $D$. canis, the so called "short-tail form" [16-17]. Today, descriptions of the short-body form are incomplete. Demodex sp. cornei has been described in different countries, and was recently described in dogs from Poland, Argentina, India and Thailand [1,18-21]. Reports with the descriptions of Demodex sp. cornei mites in dogs from Russia have not been published yet.

The aim of this study was to investigate the morphology of Demodex sp. cornei and $D$. canis found in dogs from Vladivostok.

\section{MATERIALS AND METHODS}

Samples, including skin scrapings, were taken from six household dogs with canine demodicosis (Table 2). The samples were investigated in the parasitology laboratory of the department of Marine Biodiversity and Bioresources, Far Eastern Federal University, Vladivostok during the year 2015. A modified deep skin scraping technique was used [2], and the scrapings were performed on the boundary of healthy and affected areas avoiding capillary bleeding. Specimens containing the mites of interest were fixed in $70 \%$ ethanol. For lightening, the skin scrapings were placed on a slide with a few drops of $10 \% \mathrm{NaOH}$ solution and then placed into a thermostat at $+25^{\circ} \mathrm{C}$ for 40 min. Preparations were examined under a phase contrast microscope with low and high magnification (10X, 40X and 100X). Approximately 91 mites were investigated. Total body length and size of each of the three tagma, the gnathosoma, podosoma and opisthosoma, were measured for each specimen. The ratio of opisthosoma length to body length, and the ratio of opisthosoma length to podosoma length, were calculated. The correlation between body size and Demodex sp. cornei and D. canis was evaluated via the Student's t-test. A P-value obtained via the Student's t-test of less than 0.05 was considered statistically significant.

Table 2. Summary of the anamnesis of the six observed dogs

\begin{tabular}{|c|c|c|c|c|}
\hline No & Breed/sex & Age & Symptoms & Demodex mites \\
\hline 1 & Purebred male & $\begin{array}{c}18 \\
\text { months }\end{array}$ & $\begin{array}{l}\text { Localized demodicosis, alopecia behind } \\
\text { an ear }\end{array}$ & \multirow{4}{*}{$\begin{array}{l}\text { Both forms } \\
\text { (D. canis }+ \\
\text { Demodex sp. cornei })\end{array}$} \\
\hline 2 & Crossbred male & $\begin{array}{c}5 \\
\text { months }\end{array}$ & $\begin{array}{l}\text { Localized demodicosis with alopecia } \\
\text { on the chest }\end{array}$ & \\
\hline 3 & Purebred male & $\begin{array}{c}6 \\
\text { years }\end{array}$ & $\begin{array}{l}\text { Generalized demodicosis with erythema, } \\
\text { deep pyoderma, alopecia }\end{array}$ & \\
\hline 4 & Crossbred male & $\begin{array}{c}5 \\
\text { years }\end{array}$ & $\begin{array}{l}\text { Generalized demodicosis with large } \\
\text { alopecia areas on the tail and thighs, } \\
\text { erythema on the head }\end{array}$ & \\
\hline 5 & Crossbred female & $\begin{array}{c}6 \\
\text { years }\end{array}$ & $\begin{array}{l}\text { Generalized demodicosis with alopecia, } \\
\text { erythema and deep pyoderma on thighs } \\
\text { and neck }\end{array}$ & D. canis \\
\hline 6 & Crossbred female & $\begin{array}{c}8 \\
\text { years }\end{array}$ & $\begin{array}{l}\text { Localized demodicosis with alopecia } \\
\text { on the thighs }\end{array}$ & D. canis \\
\hline
\end{tabular}




\section{RESULTS}

\section{Demodex sp. cornei and $D$. canis measurement results}

Measurement data of 52 adult $D$. canis mites (26 females, 25 males and one specimen whose sex could not be determined) and 39 adult Demodex sp. cornei mites (22 females, 14 males and three specimens whose sex could not be determined) were reported (Table 3).

Table 3. Measurement data of Demodex canis and Demodex sp. cornei

\begin{tabular}{|c|c|c|c|c|}
\hline \multirow[b]{2}{*}{ Characteristics } & \multicolumn{2}{|c|}{ Demodex sp. cornei $(\mathrm{n}=36)$} & \multicolumn{2}{|c|}{ D. canis $(\mathrm{n}=52)$} \\
\hline & $\begin{array}{l}\text { Female } \\
(\mathrm{n}=22)\end{array}$ & $\begin{array}{l}\text { Male } \\
(n=14)\end{array}$ & $\begin{array}{c}\text { Female } \\
(\mathrm{n}=26)\end{array}$ & $\begin{array}{l}\text { Male } \\
(n=25)\end{array}$ \\
\hline \multirow{3}{*}{ Length of gnathosoma $(\mu \mathrm{m})$} & 15.9 & 15.1 & 16.2 & 16.2 \\
\hline & $13.5-21.6$ & $13.5-18.9$ & 10.8-18.9 & $13.5-21.6$ \\
\hline & SD 2.1 & SD 2.3 & SD 2.1 & SD 2.2 \\
\hline \multirow{3}{*}{ Width of gnathosoma $(\mu \mathrm{m})$} & 14.8 & 14.3 & 15.1 & 13.5 \\
\hline & $13.5-16.2$ & $13.5-16.2$ & 13.5-18.9 & $13.5-16.2$ \\
\hline & SD 1.3 & SD 1.3 & SD 2 & SD 1.3 \\
\hline \multirow{3}{*}{ Length of podosoma $(\mu \mathrm{m})$} & 40.5 & 39.7 & 40.5 & 40.5 \\
\hline & $37.8-45.9$ & $27-51.3$ & $32.4-56.7$ & $16.2-48.6$ \\
\hline & SD 2 & SD 5.9 & SD 4.5 & SD 6.7 \\
\hline \multirow{3}{*}{ Width of podosoma $(\mu \mathrm{m})$} & 24.3 & 24.3 & 25.9 & 24.3 \\
\hline & $21.6-27$ & $21.6-27$ & $21.6-43.2$ & $13.5-29.7$ \\
\hline & SD 1.8 & SD 2.3 & SD 4.7 & SD 3.6 \\
\hline \multirow{3}{*}{ Length of opisthosoma $(\mu \mathrm{m})$} & 48.6 & 41.8 & 75.6 & 62.1 \\
\hline & $16.2-97.2$ & $24.3-67.5$ & $51.3-99.9$ & $40.5-110.7$ \\
\hline & SD 10 & SD 9.7 & SD 15.3 & SD 18.4 \\
\hline \multirow{3}{*}{ Width of opisthosoma $(\mu \mathrm{m})$} & 21.6 & 23.5 & 20.5 & 18.9 \\
\hline & $18.9-27$ & $21.6-29.7$ & $16.2-24.3$ & 10.8-21.6 \\
\hline & SD 2.1 & $\mathrm{SD} 2.5$ & SD 2.9 & SD 3.8 \\
\hline \multirow{3}{*}{ Total length of body $(\mu \mathrm{m})$} & 105 & 98.8 & 126.9 & 118.8 \\
\hline & $83.7-129.6$ & $86.4-116.1$ & $86.4-167.4$ & $81-148.5$ \\
\hline & SD 12.4 & SD 8.7 & SD 19.2 & SD 19.9 \\
\hline \multirow{2}{*}{$\begin{array}{l}\text { Ratio of opisthosoma length } \\
\text { to total body length }(\%)\end{array}$} & 44.7 & 42.3 & 60.8 & 52.3 \\
\hline & $12.5-47.7$ & $21.9-44.2$ & $52.9-61.6$ & $50-58.1$ \\
\hline \multirow{2}{*}{$\begin{array}{l}\text { Ratio of opisthosoma length } \\
\text { to podosoma length }(\%)\end{array}$} & 1.1 & 1.05 & 1.8 & 1.6 \\
\hline & $0.9-1.4$ & $0.8-1.5$ & $1.2-2.2$ & $1.6-2.7$ \\
\hline
\end{tabular}

Demodex sp. cornei mites had a short and wide body, and the mean total body length was $105 \pm 12.4 \mu \mathrm{m}$ in females and $98 \pm 8.7 \mu \mathrm{m}$ in males (Figure 1). The trapezoidal gnathosoma was slightly longer than it was wide. The pharyngeal bulb was horseshoe shaped, and the subgnathosoma setae were located posterolateral to the pharyngeal 
bulb. The epimeral plates were rectangular in shape. The opisthosoma was short, and made up $44.7 \%$ of the total body length (Table 3). Demodex sp. cornei mites had a rounded or slightly rounded posterior end of their opisthosoma; however, the opisthosomal organ was not present in both sexes. A band-like plate was present in the lower end of the fourth coxisternal plate. The vulva was a longitudinal slit of $4.9 \pm 0.2 \mu \mathrm{m}$ in the ventral midline just posterior to coxa IV. The aedeagus was $18.8 \pm$ $2.1 \mu \mathrm{m}$ long.

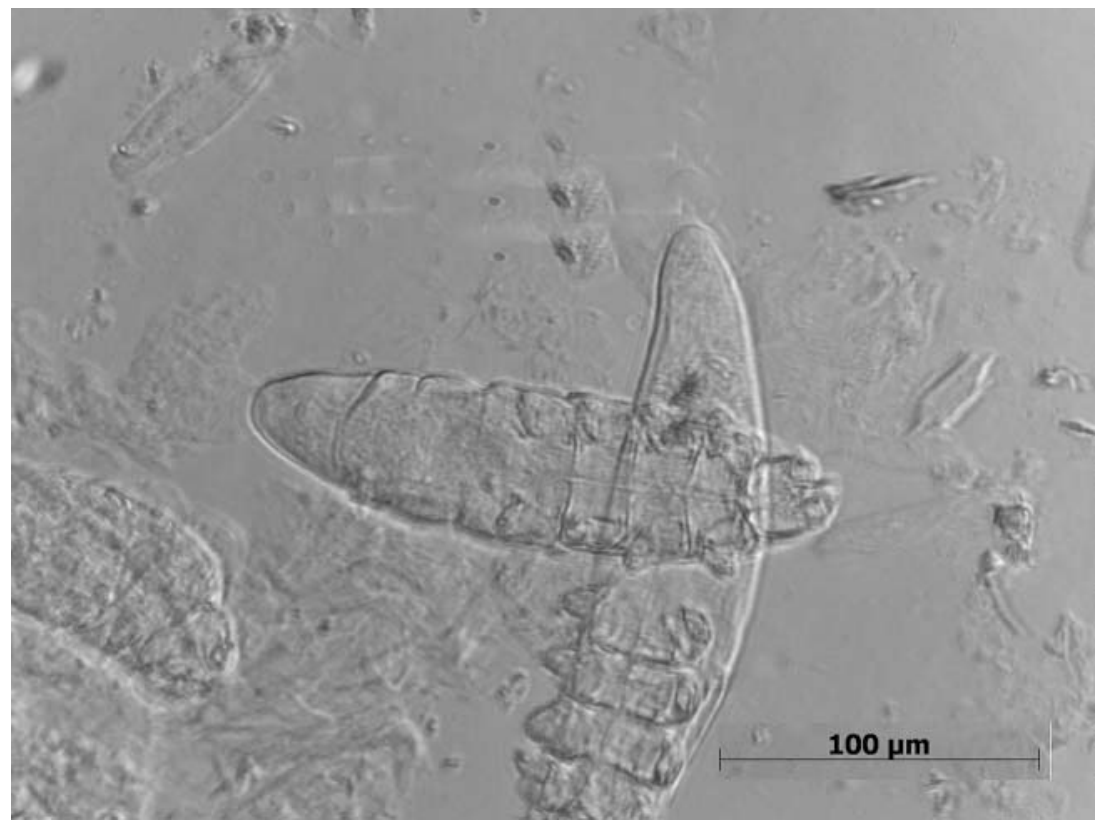

Figure 1. Demodex sp. cornei female

Demodex canis had an elongated body; the mean total body length was $126.9 \pm 19.2 \mu \mathrm{m}$ in females and $118.8 \pm 19.9 \mu \mathrm{m}$ in males (Table 3; Figures 2-3). The opisthosoma made up $52-60 \%$ of the body length. Female specimens were significantly longer than male specimens. The vulva was $4.5 \pm 0.1 \mu \mathrm{m}$ long and located in the posterior end of coxa IV. The aedeagus was $21 \pm 2.9 \mu \mathrm{m}$ long.

Demodex sp. cornei and D. canis were distinguished by the following features:

1) The total length of female Demodex sp. cornei was less than that of female D. canis: $105 \pm 12.4 \mu \mathrm{m}$ and $126.9 \pm 19.2 \mu \mathrm{m}$, respectively.

2) Demodex sp. cornei had a short opisthosoma, with opisthosoma length less than or equal to the length of the podosoma. Demodex canis had a long opisthosoma tapering to the end, with the length of the opisthosoma usually longer than the length of the podosoma by 1.2-2.7 times.

3) Demodex sp. cornei had a rounded posterior end of the opisthosoma, and D. canis had a pointed end to its body.

4) The epimeral plates were rectangular in Demodex sp. cornei and trapezoidal in D. canis. 
5) The opisthosomal organ was present in female D. canis and absent in both sexes of Demodex sp. cornei.

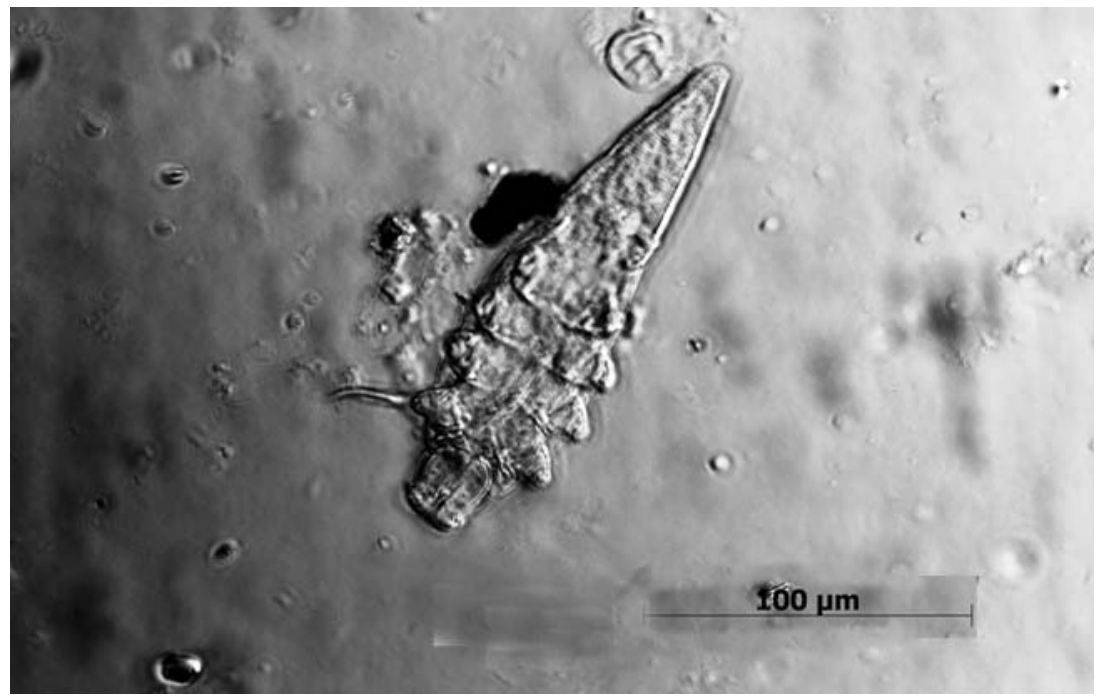

Figure 2. Demodex canis male

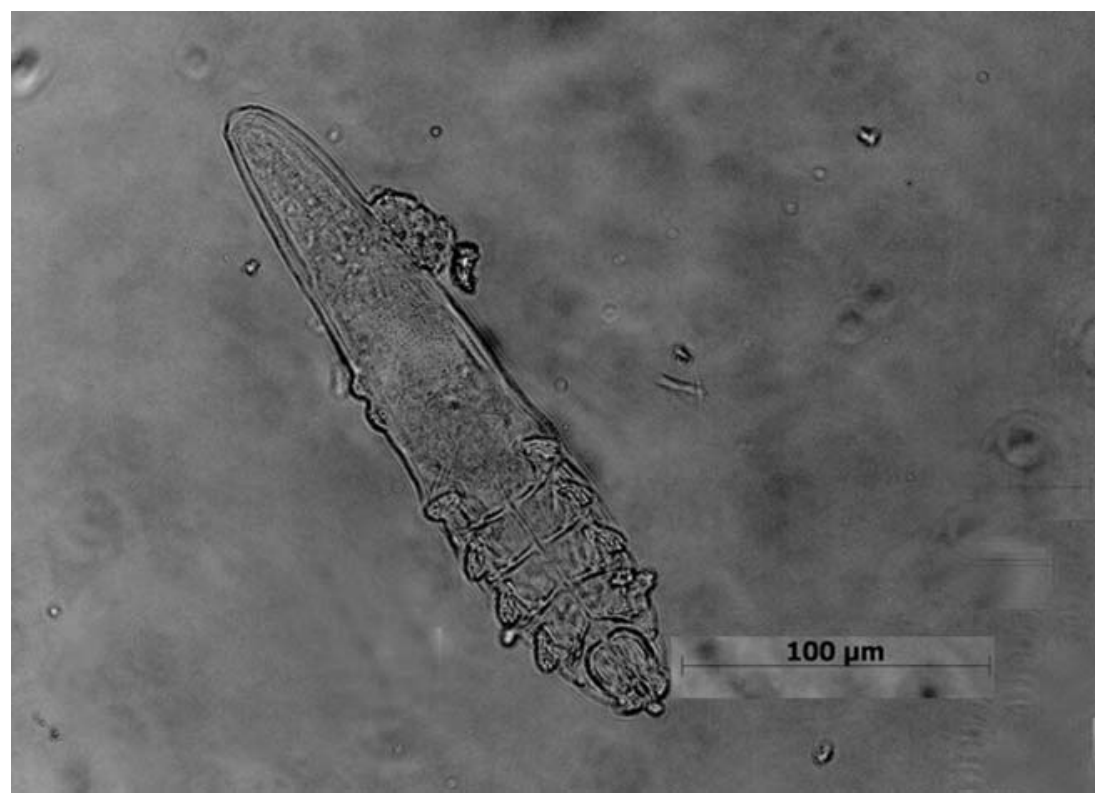

Figure 3. Demodex canis female

\section{Statistical analysis results}

The correlation between body size of two Demodex forms was estimated with the Student's t-test. A significant correlation between Demodex sp. cornei and D. canis was 
observed for total body length and length of the podosoma and opisthosoma $(p<0.05)$. A significant difference was not found between the length of the gnathosoma and Demodex sp. cornei and D. canis ( $\mathrm{p}>0.05)$.

\section{DISCUSSION}

The results from this study do not significantly differ from other studies on Demodex sp. cornei and D. canis morphology. However, Demodex sp. cornei and D. canis specimens found in the present survey were smaller than both species from other countries (Table 4). The major characteristics of Demodex sp. cornei, including the rectangular epimeral plates, the short and wide opisthosoma and the rounded posterior end of the body, were present in mites from Russia. The data from this study are in accordance with other descriptions $[1,19,20]$. The other main qualitative feature is the band-like plate in the lower end of the fourth coxisternal plate presented in Demodex sp. cornei, absented in D. canis can be observed in D. cornei only using a scanning electron microscope [15]. So, in this survey, the band-like plate was not discribed.

Table 4. Demodex sp. cornei and Demodex canis measurement data from different regions

\begin{tabular}{lcccccccc}
\hline & \multicolumn{4}{c}{ Demodex sp. cornei } & \multicolumn{4}{c}{ D. canis } \\
\cline { 2 - 9 } & $\begin{array}{l}\text { Present } \\
\text { survey }\end{array}$ & $\begin{array}{c}\text { India } \\
{[\mathbf{2 0}]}\end{array}$ & $\begin{array}{c}\text { Poland } \\
{[\mathbf{1}]}\end{array}$ & $\begin{array}{c}\text { Thailand } \\
{[\mathbf{1 8}]}\end{array}$ & $\begin{array}{c}\text { Present } \\
\text { survey }\end{array}$ & $\begin{array}{c}\text { India } \\
{[\mathbf{2 0}]}\end{array}$ & $\begin{array}{c}\text { Poland } \\
{[\mathbf{1}]}\end{array}$ & $\begin{array}{c}\text { Thailand } \\
{[\mathbf{1 8}]}\end{array}$ \\
\hline $\begin{array}{l}\text { Total length of } \\
\text { body }(\mu \mathrm{m})\end{array}$ & $98.8-105$ & 132.21 & $120.8-139.4$ & 156.9 & $118.8-126.9$ & 214.32 & $195-226$ & 217.83 \\
$\begin{array}{l}\text { Length of } \\
\text { gnathosoma }(\mu \mathrm{m})\end{array}$ & $15.1-15.9$ & 19.1 & $19.1-19.9$ & 23.5 & 16.2 & 18.89 & $25.2-26.9$ & 24.84 \\
$\begin{array}{l}\text { Length of } \\
\text { podosoma }(\mu \mathrm{m})\end{array}$ & $39.7-40.5$ & 61.06 & $52.1-53.9$ & 60.0 & 40.5 & 60.98 & $63.4-63.8$ & 60.89 \\
$\begin{array}{l}\text { Length of } \\
\text { opisthosoma }(\mu \mathrm{m})\end{array}$ & $41.8-48.6$ & 61.48 & $46.2-65.4$ & 59.25 & $62.1-75.6$ & 129.68 & $33.3-34.6$ & 147.50 \\
\hline
\end{tabular}

Correlation analyses data in this study did not considerably differ from that of other report [20], except for the correlation between podosoma size and Demodex species, which was significant in the present survey.

Some authors reported that different types of skin scrapings can help to reveal which mites Demodex sp. cornei or D. canis cause demodicosis [18,20]. This is due to the different habitats of Demodex mites: Demodex sp. cornei lives in the superficial layer of the epidermis and D. canis lives in the hair follicles. Demodex mites in different locations have different adaptive strategies and cause different symptoms in infested animals. Therefore, two demodicosis types are distinguished: superficial demodicosis, caused by $D$. canis, and surface demodicosis, caused by Demodex sp. cornei. As a result, both the deep and superficial scrapings techniques may be useful in detecting Demodex mites [18]. In this study we used the deep scraping test only, and scrapings consisted of 
samples of the stratum corneum and contents of hair follicles. However, Demodex sp. cornei and $D$. canis specimens were detected for both demodicosis types. In this study, infested dogs had localized and generalized demodicosis types, with alopecia, erythema and dermatitis. Pruritus was not present in the animals. Significant difference between demodicosis symptoms based on Demodex species was not found.

\section{CONCLUSION}

Measurement data of short-tail Demodex sp. cornei were described in Russia for the first time. These specimens do not considerably differ from other specimens described in other countries. However, a comprehensive investigation of Demodex mites is necessary for the control of canine demodicosis. The data can be interesting in the context of veterinary diagnostics and prognosis of demodicosis in dogs, and evaluation of its pathogenicity.

\section{Authors' contributions}

The author have made samples collection, specimens measurement, analysis and interpretation of data; have been involved in drafting the manuscript; have given final approval of the version to be published; and agree to be accountable for all aspects of the work in ensuring that questions related to the accuracy or integrity of any part of the work are appropriately investigated and resolved.

\section{Declaration of conflicting interests}

The author declared no potential conflicts of interest with respect to the research, authorship, and/or publication of this article.

\section{REFERENCES}

1. Izdebska JN, Fryderyk S: Diversity of three species of the genus Demodex (Acari, Demodecidae) parasitizing dogs in Poland. Pol J Environ Stud 2011, 20: 565-569.

2. Patel A, Forsythe PJ: Saunders Solutions in Veterinary Practice: Small Animal Dermatology. In: Diagnostic tests for ectoparasitism. In: Alopecia. Elsevier Health Sciences; 2008, 7-8; 154-157.

3. Ravera I, Altet L, Francino O, Sánchez A, Roldán W, Villanueva S, Bardagí M, Ferrer L: Small Demodex populations colonize most parts of the skin of healthy dogs. Vet Dermatol 2013, 24: 168-72.e37.

4. Nicolet H: Histoire naturelle des Acariens qui se trouvent aux environs de Paris. Archives du Muséum National d'Histoire Naturelle Paris, 1855, 7: 381-482.

5. Desch CE, Hillier A: Demodex injai: a new species of hair follicle mite (Acari: Demodecidae) from the domestic dog (Canidae). J Med Entomol 2003, 40: 146-149. 
6. Nutting WB, Desch CE: Demodex canis redescription and reevaluation. Cornell Vet 1978b, 68:139-149.

7. Leydig F: About hair follicle mites and itch mite. Arch Natur Berlin, 1859, 1: 338.

8. Sokolovskii VA: Zheleznica (demodekoz) sobak i ee lechenie. (Canine demodicosis and its treatment) (In Russian). Abstract of PhD thesis. Harkov; 1952, 25.

9. French JR: Biology and morphology of Demodex canis. Doctoral dissertation. Iowa State University of Science and Technology - Michigan: Frank Elwood; 1962, 108.

10. Hillier A, Desch CE: Large-bodied Demodex mite infestation in 4 dogs. J Am Vet Med Assoc, 2002, 220: 623-627.

11. Mason KV: A new species of Demodex mite with $D$. canis causing canine demodicosis: a case report. Vet Dermatol 1993, 4: 37.

12. Chen C: A short-tailed demodectic mite and demodex infestation in a Chihuahua dog. Vet Dermatol 1995, 6: 227-229.

13. Chesney CJ: Short form of Demodex species mite in the dog: occurrence and measurements. J Small Anim Pract 1999, 40: 58-61.

14. Saridomichelakis M, Koutinas A, Papadogiannakis E, Papazachariadou M, Liapi M, Trakas D: Adult-onset demodicosis in two dogs due to Demodex canis and a short-tailed demodectic mite. J Small Anim Pract 1999, 40: 529-32.

15. Tamura Y, Kawamura Y, Inoue I, Ishino S: Scanning electron microscopy description of a new species of Demodex canis spp. Vet Dermatol 2001, 12: 275-278.

16. Francino O, Ferrer L: Phylogenetic relationships in three species of canine Demodex mite based on partial sequences of mitochondrial 16S rDNA. Vet Dermatol 2012, 23: 509 e101.

17. De Rojas M, Riazzo C, Callejon R, Guevara D, Cutillas C: Molecular study on three morphotypes of Demodex mites (Acarina: Demodicidae) from dogs. Parasitol Res 2012, 111: 2165-2172.

18. Sakulploy R, Sangvaranond A: Canine Demodicosis caused by Demodex canis and short opisthosomal Demodex cornei in Shi Tzu dog from Bangkok Metropolitan Thailand. Kasetsart Veterinarians 2010, 20: 27-35.

19. Lopez R, Reyero D, Banos D: First report of canine demodicosis by short-bodied Demodex mite in Spain. Rev Inbero-Latinoam Parasitology 2011, 70: 219 - 224.

20. Sivajothi S, Sudhakara RB, Rayulu VC: Demodicosis caused by Demodex canis and Demodex cornei in dogs. J Parasit Dis 2015, 39: 673 - 676.

21. Fiorucci G, Fogel F, Paradis M: Demodex cornei: podrían ser ácaros Demodex canis transformados, moribundos o muertos. Vet Arg 2015, XXXII: 1-14. 


\section{DVE MORFOLOŠKI RAZLIČITE FORME DEMODEX PARAZITA KOD PASA SA DEMODIKOZOM U VLADIVOSTOKU (RUSIJA)}

\section{MOSKVINA Tatyana Vladimirovna}

Cilj studije je bio da se ispita morfologija Demodex canis i Demodex sp. cornei, koji su izolovani iz šest pasa kod kojih je dijagnostikovana demodikoza. Uzorci su uzimani dubokom skarifikacijom kože, oštrom kašikom. Prikazani su podaci dobijeni merenjem 52 odrasla parazita $D$. canis (26 ženki, 25 mužjaka i jedan izolat čiji pol nije mogao da se odredi) kao i 39 odrasla Demodex sp. cornei (22 ženke, 14 mužjaka i tri uzorka nedefinisanog pola). Upotrebom Studentovog t-testa, ispitivana je korelacija između veličine tela obe Demodex vrste. Postojala je značajna korelacija između formi sa kratkim i sa dugim repom i ukupne dužine tela kao i dužine podostome i opistozome $(p<0,05)$. Nije uočena značajna razlika izmežu dužine gnatostoma i forme kratkih i dugih repova ( $\mathrm{p}>0,05)$. Demodex sp. cornei i D. canis, vrste koje su nađene u Vladivostoku, bile su manje od onih koje su opisane u drugim državama. Međutim, prikazani podaci ukazuju da ne postoji značajna razlika u rezultatima drugih studija u okviru kojih su obavljana opisivanja D. canis i Demodex sp. cornei. 